\title{
Erosion wear evaluation of HVOF sprayed WC-12Co coating on some pipeline materials using Taguchi approach
}

\author{
P. Singh ${ }^{1}$, A. Bansal ${ }^{1}$, D. Kumar Goyal ${ }^{2 *}$ \\ ${ }^{1}$ Mechanical Engineering Department, Sant Longowal Institute of Engineering and Technology, Longowal, Punjab, India \\ ${ }^{2}$ Mechanical Engineering Department, IK Gujral Punjab Technical University, Main Campus, Kapurthala, Punjab, India
}

Received 5 February 2018, received in revised form 10 December 2018, accepted 13 February 2019

\begin{abstract}
Pipeline materials used for the transportation of bottom ash slurry generally suffer from intense wear due to slurry erosion. In this work, High-Velocity Oxy-Fuel (HVOF) spray process was used for the deposition of WC-12Co coating on the Mild steel, SS 304 and SS 202. Slurry erosion pot tester was used for erosion tests of uncoated and coated materials. Effects of three factors namely slurry concentration, the speed of impacting particles and erosion test duration on erosion rate were investigated using the Taguchi approach. Influence of speed of impacting particles on the erosion rate of uncoated and all the coated materials was found to be maximum, which was followed by erosion test duration and then slurry concentration. WC-12Co coating showed significant improvement in erosion wear resistance of three substrate materials namely mild steel, SS 304 and SS 202. WC-12Co coating showed the brittle mechanism of erosion wear. After the Taguchi analysis slurry erosion results were further validated with analysis of variance (ANOVA). From both ANOVA and Taguchi analysis, it was observed that the influence of speed is maximum on the erosion wear of all the uncoated as well as WC-12Co coated specimens, followed by time and slurry concentration.
\end{abstract}

K e y words: bottom ash, slurry erosion, pipeline steel, HVOF spray

\section{Introduction}

Erosion wear of pipeline materials is a serious problem faced by slurry pipelines. Bottom ash particles are highly abrasive in nature and lead to the failure of pipes due to their excessive erosion [1]. The hardness of the erodent particles is significantly higher than that of pipe materials. It has been learnt from the literature that slurry erosion resistance of the target surface can be enhanced by improving the hardness of the target surface. Further, a thermal spray coating technique is one of the simple and economical methods for improving the hardness of the target surface [2-8]. Surface coatings with very good mechanical properties can be deposited by using High-Velocity Oxy-Fuel (HVOF) thermal spray process [9]. In comparison with other flame spraying processes, HVOF process offers better adhesion of coating material on the substrate and high cohesive bond strength between deposited coating particles as this process uses low temperature and relatively very high kinetic energies [10-12]. Sidhu et al. [13] studied the microstructural and mechanical properties of HVOF sprayed WC-Co based coatings on carbon steel and found that these coatings possess lower porosity and higher microhardness values due to the presence of well-dispersed carbides in the matrix.

In the present work, HVOF sprayed WC-12Co coating deposited on the Mild steel, SS 304 and SS 202 has been studied to understand the erosion wear behaviour due to bottom ash slurry. The present study yields applicable information concerning the capability of HVOF sprayed WC-12Co coating on these three substrate materials. Also, a little or no information is available on erosion wear behaviour of these material combinations in the open literature.

\section{Experimental procedure}

\subsection{Substrate materials}

Three sheets of steel namely mild steel, SS 304

*Corresponding author: e-mail address: erdeepakgoyal81@gmail.com 
Table 1. The nominal composition of substrate materials (wt.\%)

\begin{tabular}{lccccccccc}
\hline & $\mathrm{C}$ & $\mathrm{Mn}$ & $\mathrm{Si}$ & $\mathrm{S}$ & $\mathrm{P}$ & $\mathrm{Cr}$ & $\mathrm{Ni}$ & $\mathrm{Co}$ & $\mathrm{Fe}$ \\
\hline Mild steel & 0.131 & 0.420 & 0.161 & 0.053 & 0.071 & 0.036 & 0.031 & 0.006 & Balance \\
SS 304 & 0.114 & 1.341 & 0.494 & 0.026 & 0.059 & 18.503 & 8.902 & 0.135 & Balance \\
SS 202 & 0.096 & 9.640 & 0.403 & 0.042 & 0.060 & 13.402 & 0.182 & 0.037 & Balance \\
\hline
\end{tabular}

Table 2. Details of coating powder

\begin{tabular}{lcccc}
\hline Powder & Make & Particle shape & Morphology & Particle size \\
\hline WC-12Co & H.C. Starck & Spherical & Agglomerated Sintered & $-45+15 \mu \mathrm{m}$ \\
\hline
\end{tabular}

and SS 202 used for manufacturing of the pipelines were selected as base materials in the present study. The nominal composition of these steels is given in Table 1. For the erosion tests, specimens of size $25 \mathrm{~mm} \times 25 \mathrm{~mm} \times 5 \mathrm{~mm}$ were prepared from the base materials. Before the deposition of WC-12Co coating, these specimens were polished with emery paper up to 2000 grit size, and then grit blasted with $\mathrm{Al}_{2} \mathrm{O}_{3}$ particles of 45 grit size to obtain the good adhesion between coating and substrate materials. The average microhardness of Mild steel, SS 304 and SS 202 was found to be $103 \mathrm{Hv}, 156 \mathrm{Hv}$ and $182 \mathrm{Hv}$ respectively under $50 \mathrm{gm}$ load. Also, average surface roughness $\left(R_{\mathrm{a}}\right)$ value of Mild steel, SS 304 and SS 202 was found to be $2.03,1.35$ and 1.56 respectively.

\subsection{Coating deposition}

WC-12Co powder was used to form the coating on three different substrate materials. Details of coating powder are given in Table 2. WC-12Co coating powder was deposited on given three types of substrate materials by using commercial HVOF spray gun (HIPOJET 2700) available at Harsha Speciality Welding, Panchkula, India. The steel specimens were cooled with compressed air jets during and after HVOF spraying. The HVOF spray process parameters are given in Table 3. These HVOF spray process parameters were kept constant during the entire coating process. Surface roughness tester (MITUTOYO SJ-400) was used for the measurement of surface roughness of the specimens. Diamond cutter was used to cut the specimens along the cross-section. The specimens were then polished by emery paper up to 2000 grit size, and micro-hardness of coating along the cross section was evaluated using the micro-hardness tester.

\subsection{Slurry}

Bottom ash collected from Guru Govind Singh thermal power plant, Ropar (India) was used to make a slurry. $\mathrm{SiO}_{2}, \mathrm{Al}_{2} \mathrm{O}_{3}$ and $\mathrm{CO}_{2}$ are the major con-
Ta ble 3. Process parameters employed for coating process

\begin{tabular}{lc}
\hline Process parameter & Value \\
\hline Spray distance $(\mathrm{mm})$ & $100-140$ \\
Particle size $(\mu \mathrm{m})$ & $-45+15$ \\
Air flow rate $(\mathrm{LPM})$ & 6400 \\
Oxygen flow rate $(\mathrm{LPM})$ & 260 \\
Fuel (LPG) flow rate $(\mathrm{LPM})$ & 75 \\
Powder feed rate $\left(\mathrm{g} \mathrm{min}^{-1}\right)$ & 30 \\
\hline
\end{tabular}

stituents of bottom ash. The specific gravity and weighted mean diameters of bottom ash used were 2.26 and $235 \mu \mathrm{m}$ respectively. Two slurry concentrations of 25 and 45 wt.\% were used for the experimental study.

\subsection{Experimental conditions}

A standard Taguchi experimental plan was chosen for the erosion wear evaluation, and the various operating parameters used for erosion tests are shown in Table 4. Erosion tests were conducted under 16 different experimental conditions as per full factorial design. The weight loss observations were made using microbalance and signal to noise $(S / N)$ ratio was calculated for all these cases. The selection of $S / N$ ratio depends upon the type of performance parameters and in the present study "lower is better" characteristic was chosen for the minimization of erosion wear, which was calculated as per Eq. (1) [24]:

$$
\frac{S}{N}=-10 \log \frac{1}{n}\left(\sum E_{\mathrm{R}}^{2}\right),
$$

where $n=1$, because only one observation was taken for each set of operating parameters and $E_{\mathrm{R}}$ is the weight loss for a particular set of operating parameters.

\subsection{Slurry erosion testing}

Slurry erosion pot tester (TR-401) by DUCOM 
Table 4. Levels of parameters used in the present work

\begin{tabular}{lccccc}
\hline & \multicolumn{3}{c}{ Levels } & Units \\
\cline { 2 - 5 } Control factors & I & II & III & IV & $($ rpm) \\
S: Speed & 500 & 800 & 1100 & & $($ wt. \%) \\
C: Concentration & 25 & 45 & & & $(\min )$ \\
T: Test duration & 90 & 180 & & \\
\hline
\end{tabular}

Table 5. Properties of coating

\begin{tabular}{lccc}
\hline Coating & Thickness $(\mu \mathrm{m})$ & Average microhardness $\left(\mathrm{H}_{\mathrm{v}}\right)$ & Roughness $\left(R_{\mathrm{a}}\right)$ \\
\hline WC-12Co on Mild steel & $230-250$ & $983 \pm 07$ & 5.41 \\
WC-12Co on SS 304 & $230-250$ & $1015 \pm 08$ & 5.89 \\
WC-12Co on SS 202 & $230-250$ & $972 \pm 11$ & 5.26 \\
\hline
\end{tabular}
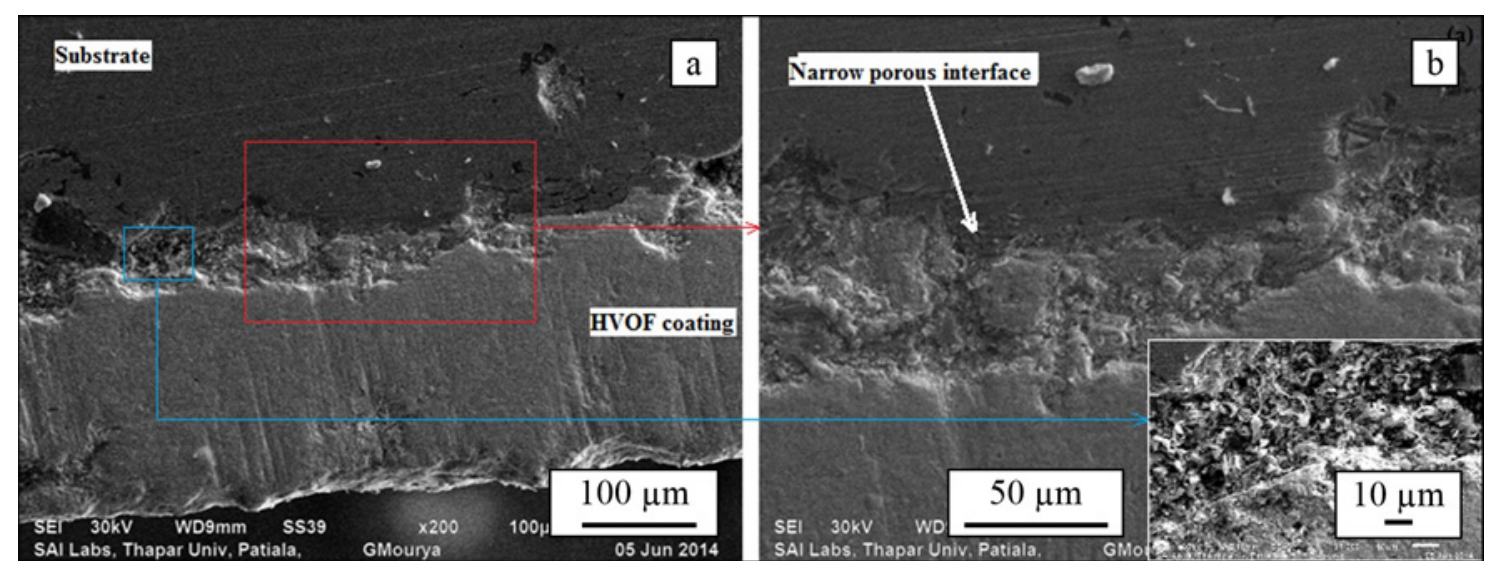

Fig. 1. Cross-sectional SEM images of WC-12Co coated Mild steel.

available at Thapar University, India was used to conducting slurry erosion tests. The slurry was prepared by mixing the bottom ash with fresh water. After each erosion test, the slurry was replaced with freshly prepared slurry. The surface of each specimen was polished with an emery paper of 150 grit size before slurry erosion tests to obtain accuracy in the results. After each erosion test, specimens were cleaned and washed with acetone and weight of specimen before and after the erosion tests was measured using electronic microbalance having $0.1 \mathrm{mg}$ least count.

\section{Results and discussion}

\subsection{Coating microstructure and XRD analysis}

In the present study JEOL, 6510LV model of scanning electron microscope (SEM) was used for crosssectional SEM images of coated WC-12Co materials. The SEM image across the cross-section of the WC-
-12 Co coating on the mild steel substrate is shown in Fig. 1. The WC-12Co coating seems to possess a splatlike laminar cross-sectional microstructure. Although there is the presence of a narrow porous interface between the coating and substrate material, continuous contact of substrate and coating seems to be defect free. In the molten splats at some interface locations, some very fine unmelted coating particles are seemed to be embedded. This is in good agreement with the previous research works carried out by T. Sudaprasert et al. and D. A. Stewart et al. [14, 15].

The XRD patterns of WC-12Co coating deposited on the Mild steel, SS 304 and SS 202 substrate materials are shown in Figs. $2 \mathrm{a}-\mathrm{c}$. Tungsten monocarbide (WC) was found to be the major phase present in the matrix as can be easily identified from XRD pattern. Also due to the decarbonization of tungsten monocarbide (WC) to the tungsten hemicarbide $\left(\mathrm{W}_{2} \mathrm{C}\right), \mathrm{W}_{2} \mathrm{C}$ phase is also present. Present XRD patterns are in good agreement with previous research works carried out by T. Sudaprasert et al. and D. A. Stewart et al. $[14,15]$. 

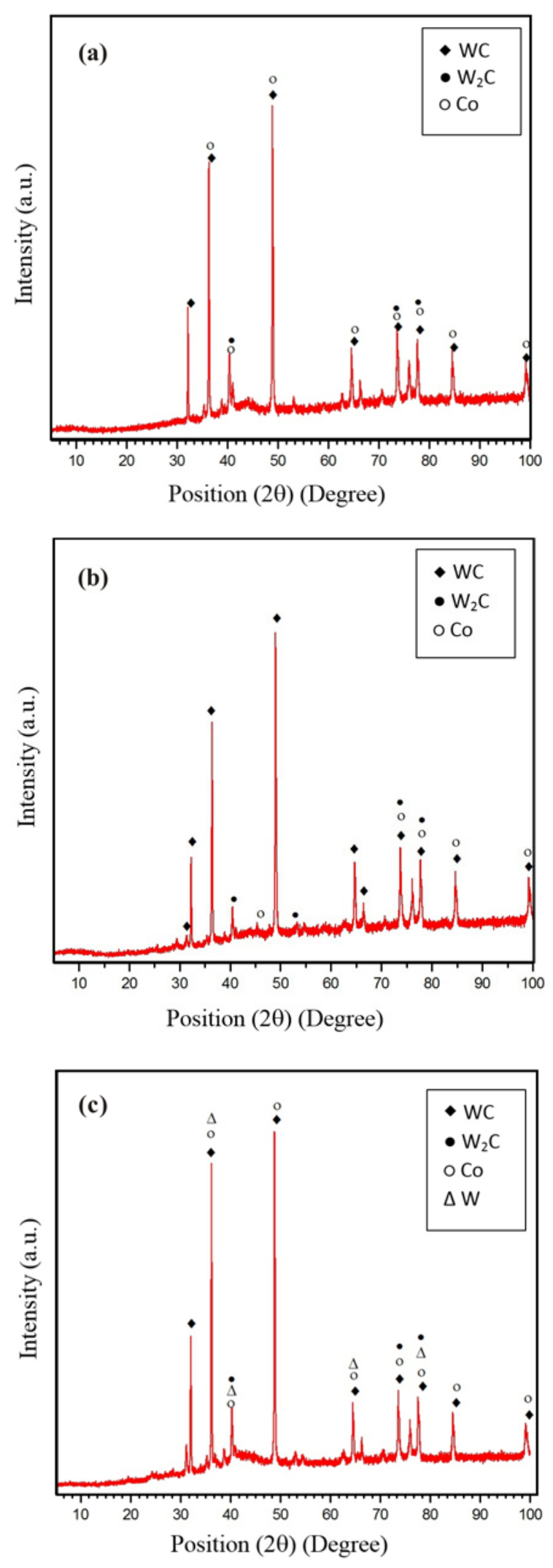

Fig. 2. (a) XRD pattern of WC-12Co coating on Mild steel, (b) XRD pattern of WC-12Co coating SS 304 steel, and (c) XRD pattern of WC-12Co coating on SS 202 steel.

\subsection{Coating properties}

WC-12Co coating thickness was measured and was found in the range of 230 to $250 \mu \mathrm{m}$ for each specimen as shown in Table 5. The average micro-hardness and surface roughness $\left(R_{\mathrm{a}}\right)$ values of WC-12Co coating on each substrate were measured and shown in Table 5. The micro-hardness value was found to be maximum for WC-12Co coating deposited on SS 304 substrate. Some variations in the micro-hardness values in the coatings were observed which may be due to voids, pores, semi-molten and unmelted coating particles present on the coating surface.

\subsection{Slurry erosion behaviour}

With the increase in revolutions of the motor, the relative speed of erodent particles concerning workpiece increases, which increases the kinetic energy of the erodent particles. It leads to more wear of the specimens [16-18]. The mass loss of all the three uncoated and WC-12Co coated materials at 45 wt.\% slurry concentration for 90 and 180 minutes is shown in Fig. 3 and for $25 \mathrm{wt} \%$ concentration mass loss results are shown in Fig. 4. From the results shown in Figs. 3 and 4 , it can be observed that the erosion rate of all the specimens increased with an increase in speed from 500 to $1400 \mathrm{rpm}$. Erosion wear rate was found to be higher in case of mild steel as compared to SS 304 and SS 202 grades of steel, which may be due to the lower micro-hardness of mild steel as compared to that of SS 304 and SS 202. SS 202 grade of steel showed the least erosion wear rate among the three types of steel which may be due to its highest microhardness value. Further, it was found that WC-12Co coated SS 202 steel showed the highest erosion resistance among the all studied materials. At 25 wt.\% slurry concentration, a similar trend has been observed as for 45 wt.\% concentration, for both of 90 and $180 \mathrm{~min}$ experiment run. Erodent particle speed has a great influence on the wear of piping materials, as it is clear from Figs. 3a and 4a. However, for a given increase in speed, increase in wear rate was found to be less and it may be due to the fact that at higher speeds erodent particle motion was highly random and led to severe inter-particle collisions which caused decrease in the momentum of erodent particles leading to decrease in mass loss at higher speeds [19-22]. For the same $180 \mathrm{~min}$ test run, mass loss is more for 45 wt.\% concentration as compared to $25 \mathrm{wt} . \%$ concentration.

\subsection{Analysis of experiments by Taguchi and ANOVA}

Influence of each control factor on the erosion wear was analysed by calculating the signal to noise ratio 

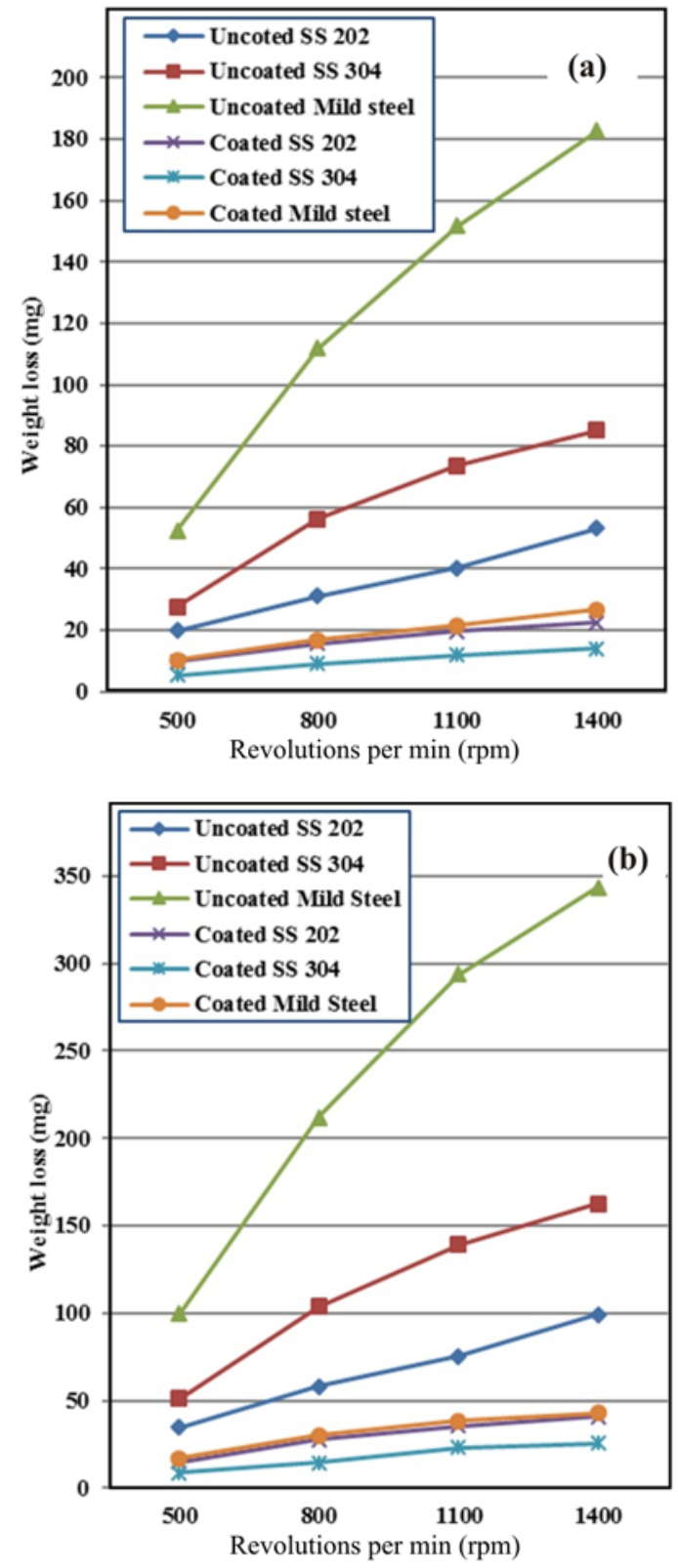

Fig. 3. Erosion of WC-12Co coated materials at 45 wt.\% concentration for (a) $90 \mathrm{~min}$ and (b) $180 \mathrm{~min}$.

$(S / N)$. With the difference between the obtained $S / N$ ratio values, the most influencing factor was determined.

The general behaviour of obtained $S / N$ ratio for an experiment is proportional to the weight loss obtained in that particular experiment, that is more is the weight loss more is the $S / N$ ratio and less is the weight loss lesser is the $S / N$ ratio. Further average $S / N$ ratio values were calculated for different levels of each parameter. From the response values of $S / N$ ratios for different levels, speed has been found to be most significant parameter followed by a time of experiment and slurry concentration in case of uncoated
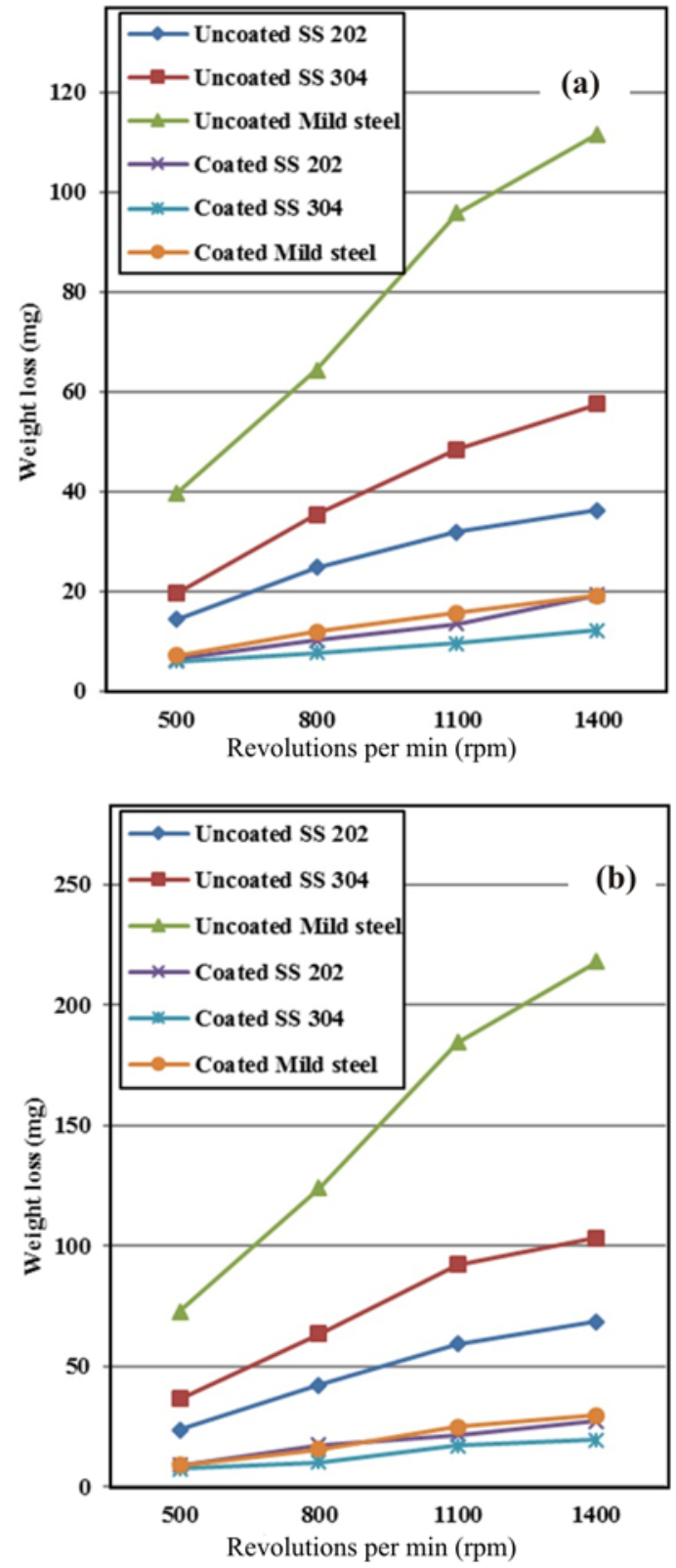

Fig. 4. Erosion of WC-12Co coated materials at 25 wt.\% concentration for (a) $90 \mathrm{~min}$ and (b) $180 \mathrm{~min}$.

as well as WC-12Co coated Mild steel, SS 304 and SS 202 specimens.

After the Taguchi analysis results are further validated with analysis of variance (ANOVA) [23, 24]. Results show the uniformity of trend found in ANOVA and Taguchi analysis for both uncoated and WC$12 \mathrm{Co}$ coated specimens. The percentage contribution of each parameter on slurry erosion was calculated using ANOVA and the influence of three different parameters: speed, concentration and time for uncoated materials is shown in Fig. 5. Percentage contribution for each of the parameters shows the domination of factors on the erosion wear. Rotational speed has been 


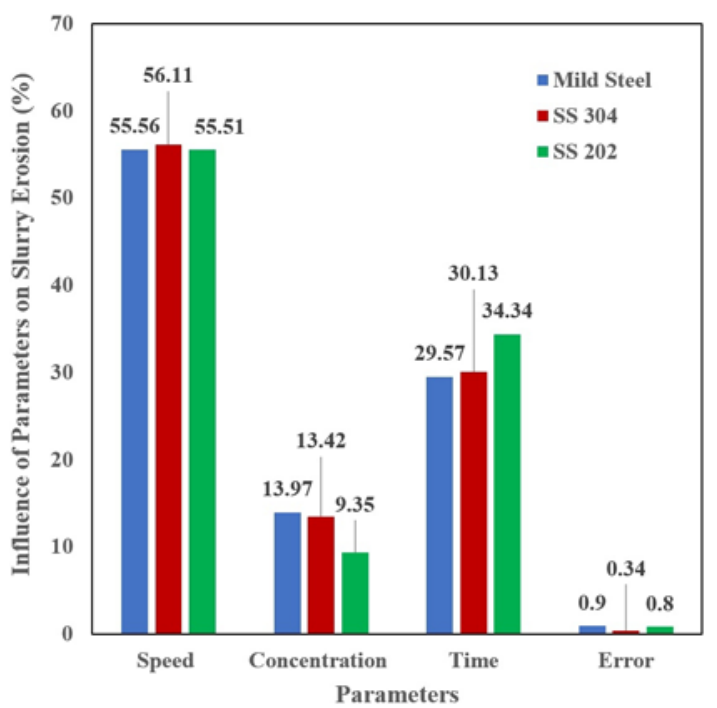

Fig. 5. Influence (\%) of parameters on erosion wear (uncoated materials).

found to have the least effect on the erosion rate of the SS 202 steel and followed by Mild steel and SS 304. This indicates that SS 202 material might be more suitable for the slurry transportation when compared on the bases of speed and slurry concentration. However, in the case of time, Mild steel might be a more suitable material for slurry transportation. From this, we can conclude that Mild steel is preferable for the long life of pipe but with this material higher slurry transportation is not recommended.

ANOVA analysis results for percentage contribution of each parameter on WC-12Co coated Mild steel, SS 304 and SS 202 specimens are shown in Fig. 6. It is noticed that effect of speed is minimum in case of WC-12Co coated SS 202 and maximum for WC-12Co coated SS 304 materials. However, the effect of slurry concentration was found to be maximum for Mild steel and minimum for SS 304.

\subsection{Examination of eroded surfaces}

Figures $7 \mathrm{a}-\mathrm{c}$ show the SEM images of eroded WC12Co coated Mild steel, SS 304 and SS 202 substrates, respectively. All the coated surfaces were tested for $180 \mathrm{~min}$ in slurry pot tester at $1400 \mathrm{rpm}$ using $45 \%$ slurry concentration. From these images, it can be observed that the erosion of WC- 12 Co coating is mainly because of brittle wear mechanisms and slightly ductile erosion wear is detected on the coating of the mild steel substrate. Mainly crater lip, carbide fracture and carbide pull-out wear mechanisms were observed from the SEM images, while "micro cutting" had been found dominating in case of coated mild steel materials. It might be due to more splats, splat bound-

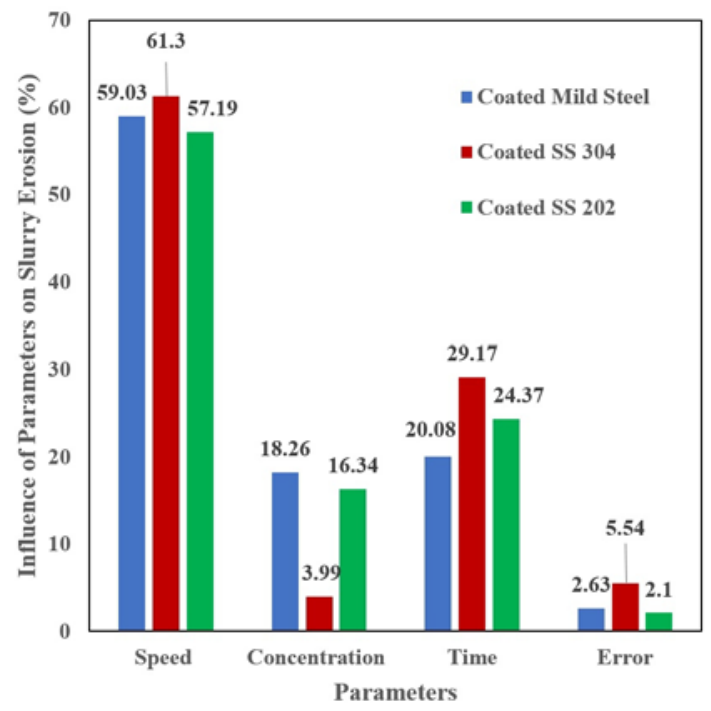

Fig. 6. Influence (\%) of parameters on erosion wear (WC12 Co coated materials).

aries and melted particles of coatings. Conversion of tungsten monocarbide (WC) into tungsten hemicarbide $\left(\mathrm{W}_{2} \mathrm{C}\right)$ might be another cause for the "micro cutting" because tungsten hemicarbide $\left(\mathrm{W}_{2} \mathrm{C}\right)$ is less hard material [25-27].

\section{Conclusions}

Investigations of the parameters affecting the erosion wear of slurry pipeline materials and coatings have been carried out in the present work, and weight loss results obtained were further investigated with the Taguchi and ANOVA approach to study the percentage influence of parameters on the erosion wear. Erosion wear of uncoated and WC-12Co coated Mild steel, SS 304 and SS 202 was studied. Following conclusions have been drawn from the present study:

- SS 202 showed best erosion resistance followed by SS 304 and Mild steel under all the experimental conditions.

- Significant improvement in hardness was observed in case of WC-12Co coated materials.

- WC-12Co coating shows considerable improvement in erosion wear resistance of all the three substrate materials namely Mild steel, SS 304 and SS 202.

- Brittle wear mechanism was noticed in WC-12Co coatings.

- It has been observed from Taguchi results, the influence of speed is maximum on the erosion wear of all the uncoated as well as WC-12Co coated specimens and followed by time and slurry concentration, which is also validated with ANOVA. 

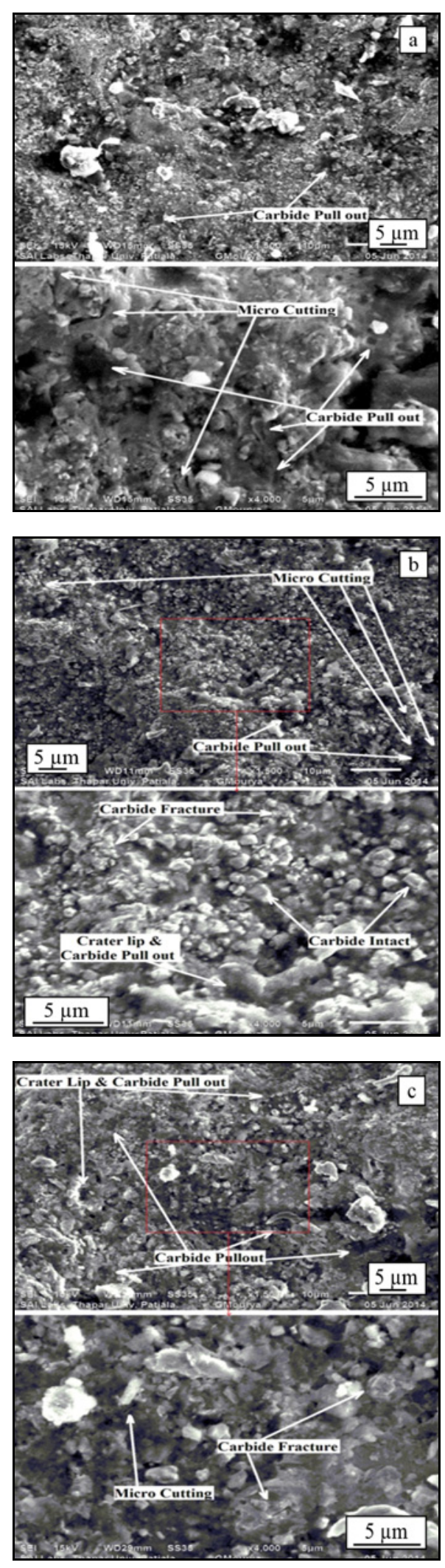

Fig. 7. SEM images of eroded WC-12Co coated (a) Mild steel, (b) SS 304, and (c) SS 202 materials for 180 min at $1400 \mathrm{rpm}$ using 45 wt.\% slurry concentration.

\section{References}

[1] Gupta, R., Singh, S. N., Seshadri, V.: Wear, 184, 1995, p. 169. doi:10.1016/0043-1648(94)06566-7

[2] Patil, M. S., Deore, E. R., Jahagirdar, R. S., Patil, S. V.: Proceedings of the World Congress on Engineering, 8, 2011, p. 978. ISBN: 978-988-19251-5-2. ISSN: 20780958 (Print). ISSN: 2078-0966 (Online).

[3] Stokes, J., Looney, L.: Surface and Coatings Technology, 177-178, 2004, p. 18. doi:10.1016/j.surfcoat.2003.06.003

[4] Picas, J. A., Forn, A., Matthaus, G.: Wear, 261, 2006, p. 477. doi:10.1016/i.wear.2005.12.005

[5] Sidhu, H. S., Sidhu, B. S., Prakash, S.: Surface and Coatings Technology, 202, 2007, p. 232. doi:10.1016/j.surfcoat.2007.05.035

[6] Wang, Y., Yang, Y., Yan, M. F.: Wear, 263, 2007, p. 371. doi:10.1016/i.wear.2006.12.003

[7] Fang, W., Cho, T. Y., Yoon, J. H., Song, K. O., Hur, S. K., Youn, S. J., Chun, H. G.: Journal of Materials Processing Technology, 209, 2009, p. 3561. doi:10.1016\%2Fj.imatprotec.2008.08.024

[8] Shivamurthy, R. C., Kamaraj, M., Nagarajan, R., Shariff, S. M., Padmanabham, G.: The Minerals, Metals and Materials Society A, 41, 2009, p. 470. doi:10.1007/s11661-009-0092-y

[9] Schwetzke, R., Kreye, H.: Journal of Thermal Spray Technology, 8, 1999, p. 433. doi:10.1361/105996399770350395

[10] Cho, T. Y., Yoon, J. H., Kim, K. S., Song, K. O., Joo, Y. K., Fang, W., Zhang, S. H., Youn, S. J., Chun, H. G., Hwang, S. Y.: Surface and Coatings Technology, 202, 2008, p. 5556. doi:10.1016/j.surfcoat.2008.06.106

[11] Bolleli, G., Lusvarghi, L., Barletta, M.: Wear, 267, 2009, p. 944. doi:10.1016/j.wear.2008.12.066

[12] Cho, T. Y., Yoon, J. H., Cho, J. Y., Joo, Y. K., Kang, J. H., Zhang, S., Chun, H. G., Hwang, S. Y., Kwon, S. C.: Surface and Coatings Technology, 203, 2009, p. 3250. doi:10.1016/i.surfcoat.2009.04.003

[13] Sidhu, H. S., Sidhu, B. S., Prakash, S.: Journal of Materials Processing Technology, 171, 2006, p. 77. doi:10.1016/j.jmatprotec.2005.06.058

[14] Sudaprasert, T., Shipway, P. H., McCartney, D. G.: Wear, 255, 2003, p. 943. doi:10.1016/S0043-1648(03)00293-X

[15] Stewart, D. A., Shipway, P. H., McCartney, D. G.: Acta Materialia, 48, 2000, p. 1593. doi:10.1016/S1359-6454(99)00440-1

[16] Wang, Q., Chen, Z. H., Ding, Z. X.: Tribology International, 42, 2009, p. 1046.

[17] Babu, P. S., Basu, B., Sundararajan, G.: Wear, 268, 2010, p. 1387. doi:10.1016/j.wear.2010.02.013

[18] Ramesh, M. R., Prakash, S., Nath, S. K., Sapra, P. K., Venkataraman, B.: Wear, 269, 2010, p. 197. doi:10.1016/j.wear.2010.03.019

[19] Kasem, A. A.: Journal of Tribology, 133, 2011, p. 014502. doi:10.1115/1.4002605

[20] Goyal, D. K., Singh, H., Kumar, H., Sahni, V.: Wear, 289, 2012, p. 46. doi:10.1016/j.wear.2012.04.016

[21] Thakur, L., Arora, N.: Wear, 303, 2013, p. 405. doi:10.1016/j.wear.2013.03.028

[22] Goyal, D. K., Singh, H., Kumar, H., Sahni, V.: Journal of Tribology, 136, 2014, p. 1. doi:10.1115/1.4027621 
[23] Mishra, S. C., Praharaj, S., Satpathy, A.: Journal of Manufacturing Engineering, 4, 2009, p. 241.

[24] Srinivasulu, M., Komaraiah, M., Rao, C. S. K. P.: In: Proceedings of ICETME '2011. Ed.: Chhibber, R. Patiala, Thapar University 2011, p. 431.

[25] Venter, A. M., Oladijo, O. P., Luzin, V., Cornish, L. A., Sacks, N.: Thin Solid Films, 549, 2013, p. 330. $\underline{\text { doi:10.1016/j.tsf.2013.08.075 }}$
[26] Zhang, S. H., Cho, T. Y., Yoon, J. H., Li, M. X., Shum, P. W., Kwon, S. C.: Material Science and Engineering B, 162, 2009, p. 127. doi:10.1016/j.mseb.2009.03.017

[27] Enayati, M. H., Karimzadeh, F., Jafari, M., Markazi, A., Tahivilian, A.: Wear, 309, 2014, p. 192. doi:10.1016/j.wear.2013.10.015 